\begin{tabular}{c|c|c}
\hline \hline Vol. 273: 65-79, 2004 & MARINE ECOLOGY PROGRESS SERIES \\
Mar Ecol Prog Ser & Published June 8 \\
\hline \hline
\end{tabular}

\title{
Influence of animals on turbulence in the sea
}

\author{
Mark E. Huntley ${ }^{1, *}$, Meng Zhou ${ }^{2}$ \\ ${ }^{1}$ Hawaii Institute of Marine Biology, University of Hawaii, PO Box 1346, Kaneohe, Hawaii 96740, USA \\ ${ }^{2}$ Department of Environmental Coastal and Ocean Sciences, University of Massachusetts Boston, 100 Morrissey Boulevard, \\ Boston, Massachusetts 02125, USA
}

\begin{abstract}
Analysis of data on the hydrodynamics of swimming by 100 species, ranging in body mass $(M)$ from bacteria to blue whales, leads to a model of animal-induced turbulence in the ocean. Swimming speeds and Reynolds number (Re) are strongly correlated with body mass, both at typical cruising speeds and at escape speeds associated with predator-prey interactions. We find that animals operating at $\mathrm{Re}>1000$ typically form schools that are concentrated by many orders of magnitude above their average abundance. We calculate the rate of kinetic energy production by 11 representative species of schooling animals ranging in size from euphausiids to whales, and find it to be of the order of $10^{-5} \mathrm{~W} \mathrm{~kg}^{-1}$, regardless of animal size. Animal-induced turbulence is comparable in magnitude to rates of turbulent energy dissipation $(\varepsilon)$ that result from major storms. The horizontal length scale (10 to $1000 \mathrm{~m}$ ) of energy production rate by animal schools is comparable to the observed fine-scale variability in $\varepsilon$. We present detailed case studies of 4 species-Atlantic bluefin tuna, Norwegian herring, northern anchovy and Antarctic krill - all of which have schooling behavior that places them within the zone of maximum seasonal stratification where their energy production rate would be 3 to 4 orders of magnitude greater than the background average rate of turbulent energy dissipation. We conclude that schooling animals are an important source of fine-scale turbulent mixing in the ocean, especially in coastal regions during summer.
\end{abstract}

KEY WORDS: Turbulence $\cdot$ Animal swimming $\cdot$ Epsilon

Resale or republication not permitted without written consent of the publisher

\section{INTRODUCTION}

Ocean turbulence at all scales is generated by a variety of energy sources that create instabilities. Winds, waves and currents are the commonly recognized sources of turbulent energy in the ocean (Pond \& Pickard 1989). Waves at the ocean surface give rise to turbulent energy when they break. Internal waves can become unstable and break up into turbulence as they propagate through vertical density gradients. Surface winds create shear that can lead to instabilities, causing flow to become turbulent. At relatively large scales, the shear instabilities along permanent currents such as the Gulf Stream create geostrophic turbulence in the form of long-lived eddies.

Turbulent energy is transferred from large to small scales via the energy cascade. Large eddies break into smaller eddies, but turbulent energy is not dissipated until the eddy scale becomes small enough to be dominated by molecular viscosity. At this scale, viscous forces overcome the velocity gradients and the kinetic energy of turbulent motion is finally converted to heat.

Marine animals are often viewed as the subjects of turbulence. Rothschild \& Osborn (1988) advanced the theory that, at scales of the individual animal, turbulence would enhance prey contact rates and effectively increase food availability. Indeed, feeding by copepods and larval fish is enhanced at moderate levels of turbulence, but diminished at higher levels (Kiørboe \& Saiz 1995, MacKenzie \& Kiørboe 2000, Visser et al. 2001). Turbulence can alter copepod swimming behavior, inducing changes in the frequency of swimming events and eliciting high-speed escape reactions (Costello et al. 1990, Hwang \& Strickler 1994, Caparroy et al. 1998). Microscale turbulence acts similarly on larval fish activity levels (MacKenzie \& Kiørboe 1995, Dower et al. 1997). 
Individual animals are also well recognized as a source of turbulence. Many animals typically swim at speeds that produce turbulent flow, leaving added kinetic energy in their wake (Vogel 1981, Azuma 1992). Modern hydrodynamic analysis of swimming was pioneered almost simultaneously in studies of crustaceans, fishes and cetaceans (Lighthill 1970, Vlymen 1970, Wu 1971). Research was initially focused on elucidating the mechanics of swimming and estimating hydrodynamic characteristics. More recently, the nature of vortex trails created by swimming fishes has come to light through the use of particle image velocimetry and greatly enhanced computational power (Müller et al. 1997, Cheng \& Chahine 2001, Videler et al. 2002). However, studies of animal swimming have tended to focus primarily on energetic consequences for the animal rather than on energetic consequences for the fluid medium. Swimming animals transfer energy into the water that must ultimately be dissipated on the scale of the individual. What happens at larger scales? Is it possible, for example, that a school of fish could effectively mix the pycnocline? These questions appear to be unanswered.

In this paper we investigate the proposition that animal kinetic energy is an important source of turbulence in the ocean. We quantify the rate of energy production of individual animals, and show it to be related

Table 1. Variables, definitions and units

\begin{tabular}{|c|c|c|}
\hline Variable & Definition & Unit \\
\hline$a$ & Mass-normalized swimming velocity constant & $\mathrm{m} \mathrm{s}^{-1} \mathrm{~kg}^{-\lambda}$ \\
\hline$A_{z}$ & Vertical kinematic eddy viscosity & $\mathrm{m}^{2} \mathrm{~s}^{-1}$ \\
\hline$C_{\mathrm{D}}$ & Coefficient of total drag for an individual animal & \\
\hline$D$ & Total drag caused by a swimming animal & $\mathrm{kg} \mathrm{m} \mathrm{s} \mathrm{s}^{-2}$ \\
\hline$e_{\mathrm{d}}$ & $\begin{array}{l}\text { Rate of energy utilization to overcome drag } \\
\text { by an individual animal (in W) }\end{array}$ & $\mathrm{kg} \mathrm{m}^{2} \mathrm{~s}^{-3}$ \\
\hline$e_{\mathrm{t}}$ & $\begin{array}{l}\text { Total rate of energy utilization by an individual } \\
\text { animal (in W) }\end{array}$ & $\mathrm{kg} \mathrm{m}^{2} \mathrm{~s}^{-3}$ \\
\hline$E_{\mathrm{p}}$ & $\begin{array}{l}\text { Total rate of animal energy production per unit } \\
\text { mass of seawater }\end{array}$ & $\mathrm{W} \mathrm{kg}^{-1}$ \\
\hline$\varepsilon$ & Rate of turbulent energy dissipation & $\mathrm{W} \mathrm{kg}{ }^{-1}$ \\
\hline$\lambda$ & Swimming velocity exponent of mass & \\
\hline$\eta$ & Propulsive efficiency & \\
\hline$L$ & Animal body length & $\mathrm{m}$ \\
\hline$M$ & Animal body wet mass of an individual animal & $\mathrm{kg}$ \\
\hline$N$ & Number of animals & \\
\hline$N / V$ & $\begin{array}{l}\text { Abundance of animals: number of animals per } \\
\text { unit volume of seawater }\end{array}$ & $\mathrm{m}^{-3}$ \\
\hline$v$ & Kinematic molecular viscosity of seawater & $\mathrm{m}^{2} \mathrm{~s}^{-1}$ \\
\hline $\operatorname{Re}$ & Reynolds number $(u L / v)$ & \\
\hline$\rho$ & Density of seawater & $\mathrm{kg} \mathrm{m}^{-3}$ \\
\hline$S_{\mathrm{w}}$ & Wetted surface area of an individual animal & $\mathrm{m}^{2}$ \\
\hline$u_{\mathrm{c}}$ & Cruising speed & $\mathrm{m} \mathrm{s}^{-1}$ \\
\hline$u_{\mathrm{e}}$ & Escape speed & $\mathrm{m} \mathrm{s}^{-1}$ \\
\hline$V$ & Volume of seawater & $\mathrm{m}^{3}$ \\
\hline$W$ & Animal body width & $\mathrm{m}$ \\
\hline
\end{tabular}

to body mass. We then estimate energy production rates at scales of social aggregation. Finally, we compare the resultant rate of kinetic energy production with observed rates of turbulent energy dissipation. We consider 4 species in detail: Atlantic bluefin tuna, northern anchovy, Norwegian spring-spawning herring, and Antarctic krill. We identify rules that apply to school dimensions, their packing density, their location in the water column, and the kinetic energy they produce at relevant scales in time and space.

\section{DATA AND DEFINITION OF TERMS}

We present data on swimming speeds of 98 species in 9 taxonomic categories that include one bacterium, 4 species of protozoans, 24 species of crustaceans, 1 mollusc, 41 species of fishes, 2 species of reptiles, 3 species of birds (penguins), and 22 species of mammals (Appendix 1 at www.int-res.com/journals/ suppl/huntley_appendix.pdf). All the empirical constants presented de novo in this article, with the exception of those for the relationship between packing density and animal mass, are based on the data summarized in Appendix 1. Table 1 includes the definitions and, where appropriate, dimensions of all variables and constants.

Swimming speed. We distinguish between 2 characteristic swimming modes: cruising and escape. Cruising speed is that which can be maintained for long periods of time, or indefinitely, depending upon the species. Escape speed is maintained for only brief periods while an animal escapes a predator or pursues prey; in the fish literature this mode is referred to as burst swimming (e.g. Fish et al. 1991).

The definition of swimming speed depends upon the taxonomic group under consideration. In fishes, cruising speed is best defined as the metabolically optimal swimming speed, at which the work per distance traveled, measured as oxygen consumption in $\mathrm{J} \mathrm{m}^{-1}$, is minimal (Videler \& Nolet 1990). Few measurements exist of oxygen consumption for swimming mammals, so their cruising speeds are usually known only from direct observations. Swimming of many crustaceans is not continuous, especially at low Reynolds numbers (Re). This is particularly true of microcrustaceans such as copepods; their cruising behavior 
involves a succession of motion events, characterized by an initial period of acceleration as the swimming legs move propulsively, and followed by a coasting period as the legs resume their initial position (Morris et al. 1990). For copepods, therefore, we use average cruising speeds.

We define escape speed operationally, as the greatest recorded speed for a given species. Its sustainability increases with animal size. The cyclopoid copepod Cyclops scutifer can maintain an escape velocity of $\sim 20 \mathrm{~cm} \mathrm{~s}^{-1}$ for only a fraction of a second (Strickler 1975). The threespine stickleback Gasterosteus aculeatus, maintains its peak velocity of approximately $35 \mathrm{~cm} \mathrm{~s}^{-1}$ for $1 \mathrm{~min}$ (Whoriskey \& Wooton 1987). The gray whale Eschrichtius robustus has an escape velocity of $4.4 \mathrm{~m} \mathrm{~s}^{-1}$ (Gilmore 1956), and can maintain a velocity of $3.6 \mathrm{~m} \mathrm{~s}^{-1}$ for almost $4 \mathrm{~h}$ (Wolman 1985).

Body mass and body length. We used wet body weight to scale swimming speeds to body mass. This unit of mass is commonly reported for relatively large animals such as fishes, birds and mammals. For crustaceans, body mass is often reported only in terms of dry weight or total carbon; sometimes the only measure of size is body length. To convert these units to wet weight we used a conversion factor of 5 for dry weight and 12.5 for carbon (Omori \& Ikeda 1984); to convert from body length we assumed a length:width ratio of 7:1 (Huntley et al. 1995), approximated shape as a cylinder and assumed a body density equivalent to water $\left(1.0 \mathrm{~g} \mathrm{~cm}^{-3}\right)$. Body weights of protozoans and bacteria were also estimated from body volume, assuming a density of $1.0 \mathrm{~g} \mathrm{~cm}^{-3}$. We followed conventional definitions of body length, employing, for example, prosome length for copepods and fork length for fishes.

Animal aggregations. We cite a variety of literature sources regarding the dimensions and behavior of swarms or schools. Dimensions include the average horizontal length scale, aggregation thickness, and the average depth interval occupied by the species; we also present data on maximum dimensions when these have been reported. The data on packing density, or number of individuals per unit volume of seawater, within aggregations is primarily based upon in situ photographic observations where possible, though some acoustic data is included when direct observations were not available.

\section{RESULTS AND DISCUSSION}

\section{Swimming speed in relation to body mass}

Over a range of 20 orders of magnitude in body mass, from the bacterium Escherichia coli $(5.2 \times$ $10^{-16} \mathrm{~kg}$ ) to the blue whale Balaenoptera musculus

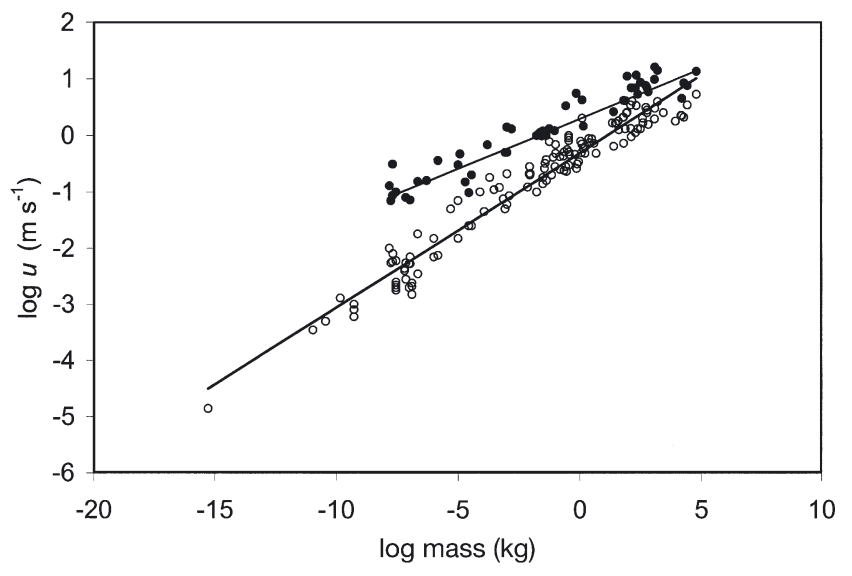

Fig. 1. Swimming velocity $\left(\mathrm{m} \mathrm{s}^{-1}\right)$ as a function of body mass $(\mathrm{kg})$ of animals while cruising $(0)$ and escaping $(\bullet)$

$\left(6.4 \times 10^{4} \mathrm{~kg}\right)$, swimming speed is described by the power function $\left(\mathrm{m} \mathrm{s}^{-1}\right)$ :

$$
u_{c, e}=a M^{\lambda}
$$

where $u_{\mathrm{c}}$ is the cruising speed (or $u_{\mathrm{e}}$ the escape speed) and $M$ is the wet body mass $(\mathrm{kg})$. At cruising speed, we obtain values of $a=0.483 \mathrm{~m} \mathrm{~s}^{-1} \mathrm{~kg}^{-\lambda}$ and $\lambda=0.275(\mathrm{n}=$ $140, \mathrm{r}^{2}=0.95$ ) (Fig. 1). For escape speed, $a=2.27 \mathrm{~m} \mathrm{~s}^{-1}$ $\mathrm{kg}^{-\lambda}$, and $\lambda=0.178\left(\mathrm{n}=40 ; \mathrm{r}^{2}=0.91\right)$ (Fig. 1). Thus, per unit mass, larger animals cruise more slowly than small animals. The mass-dependent effect is enhanced at escape speed. Large mammals are able to double or triple their speed during escape behavior, but the escape speed of small copepods is almost 2 orders of magnitude greater than their normal cruising speed.

\section{Reynolds number in relation to body mass and swimming velocity}

Re characterizes the nature of fluid flow as a function of the length scale $(L)$ the cruising or escape speed $\left(u_{c, \mathrm{e}}\right)$ and the kinematic molecular viscosity $(v)$ from

$$
\operatorname{Re}=\frac{u_{\mathrm{c}, \mathrm{e}} L}{v}
$$

For seawater $v$ has a value of $\sim 1.4 \times 10^{-6} \mathrm{~m}^{2} \mathrm{~s}^{-1}$ (Pond \& Pickard 1989). At low Re, flow is dominated by viscous forces and is laminar; however, above a transition value of $\operatorname{Re} \sim 1000$, inertial forces become important and flow becomes increasingly turbulent.

Re is a power function of body mass (Fig. 2), which for cruising speed is described by

$$
\mathrm{Re}_{\mathrm{c}}=1.46 \times 10^{5} M^{0.63}
$$

( $\left.n=140, r^{2}=0.98\right)$, and for escape speed by 


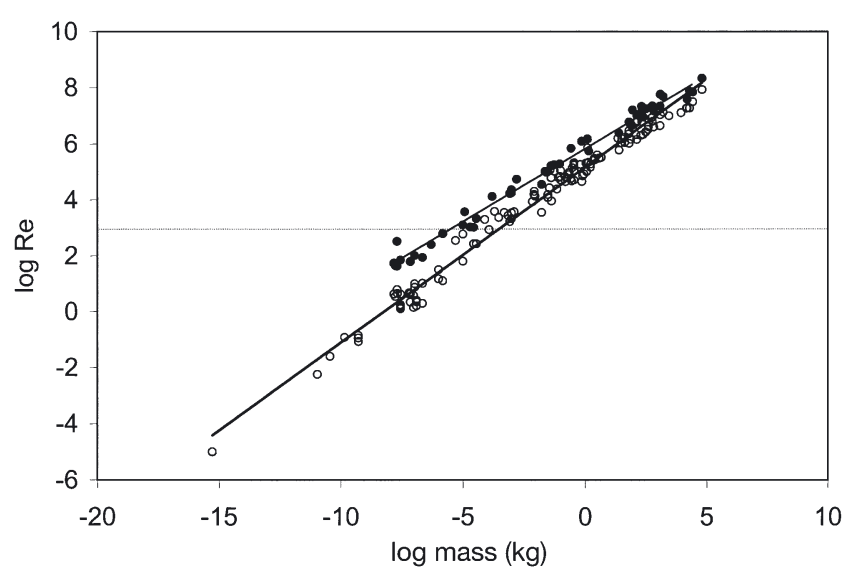

Fig. 2. Reynolds number (Re) as a function of body mass (kg) for animals at cruising ( $(\circ)$ and escape $(\bullet)$ speeds. Dashed line indicates the approximate value of the transition $\mathrm{Re}$

$$
\operatorname{Re}_{\mathrm{e}}=6.69 \times 10^{5} M^{0.52}
$$

$\left(\mathrm{n}=40, \mathrm{r}^{2}=0.99\right)$. Although the transition to turbulence at cruising speed applies to animals in the size range of small fishes and large crustaceans such as shrimps and crabs $\left(M \sim 10^{-3} \mathrm{~kg}\right)$, at escape speeds the transition occurs at a body mass 2 orders of magnitude smaller $\left(M \sim 10^{-5} \mathrm{~kg}\right)$, equivalent to that of very large copepods (e.g. Pleuromamma xiphias), euphausiids (e.g. Euphausia pacifica) and larval fish (e.g. Clupea harengus).

Regression of log-transformed cruising speed $\left(u_{\mathrm{c}}\right)$ against Re (Fig. 3) yielded

$$
u_{c}=2.5 \times 10^{-3} \mathrm{Re}^{0.44}
$$

$\left(n=140, r^{2}=0.99\right)$ and, for escape speed $\left(u_{\mathrm{e}}\right)$,

$$
u_{\mathrm{e}}=2.23 \times 10^{-2} \mathrm{Re}^{0.35}
$$

$\left(\mathrm{n}=40, \mathrm{r}^{2}=0.95\right)$. In their analysis of optimal swimming speeds for relatively large animals, $>10^{-4} \mathrm{~kg}$, Videler \& Nolet (1990) found $u_{\mathrm{c}}=2.00 \times 10^{-3} \mathrm{Re}^{0.47}$ - almost identical to our finding for cruising speeds (Eq. 5). We find here that this relationship holds for organisms down to $10^{-16} \mathrm{~kg}$ (Fig. 3). Escape speeds, however, are much greater at a given Re (Eq. 6).

\section{Contribution of animals to turbulence in the sea}

We focus on the following key questions: (1) How much kinetic energy is produced by animals swimming in the ocean? (2) Is the magnitude of animalinduced turbulence significant by comparison to observed rates of turbulent energy dissipation? (3) What are the relevant time and space scales of animal-induced turbulence?

The mechanism by which turbulence is produced by animal swimming is different from that produced by shear. Swimming-induced turbulence is caused by velocity fluctuations arising from animal motion at relatively small scales rather than by the interaction between Reynolds stress and the shear of the mean flow. Nevertheless, the kinetic energy that is produced ultimately must be dissipated.

The rate of turbulent energy dissipation caused by animals arises from the rate at which they expend energy. Animals consume energy to overcome the drag force created by swimming. The rate of energy expenditure by an individual animal, $e_{\mathrm{d}}$, is the product of its swimming speed and the work it does to overcome drag, i.e.

$$
e_{\mathrm{d}}=D u_{\mathrm{C}}
$$

where $D$ is the drag force. The total drag $(D)$ is primarily caused by flow separation and loss of energy in the wake of the animal, as well as from skin friction. In general, skin friction reflects viscous forces and becomes significantly less important at high Re. The total drag (in $\mathrm{N}$ ) is written as:

$$
D=\frac{1}{2} \rho u_{\mathrm{c}}^{2} S_{\mathrm{w}} C_{\mathrm{D}}
$$

where $\rho$ is the density of seawater, $S_{\mathrm{w}}$ is the total wetted surface area, and $C_{\mathrm{D}}$ is the drag coefficient. Here we approximate the wetted surface area as $S_{\mathrm{w}}=2 W L$, where $W$ is body width and $L$ is body length. Surface area can be more accurately defined for animals that share a common shape (e.g. Fish 1993), but this general expression is reasonable for the variety of shapes considered here.

The theoretical drag coefficient, $C_{\mathrm{D}}$, for turbulent flow is given as:

$$
C_{\mathrm{D}}=0.072 \mathrm{Re}^{-0.2}
$$

(Hoerner 1965), which describes the drag on an ideal flat plane parallel to the flow where the boundary layer

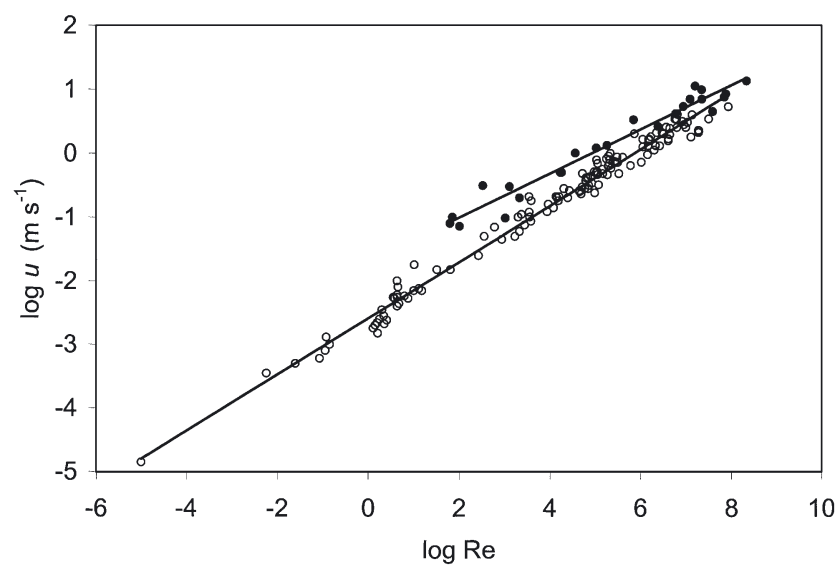

Fig. 3. Swimming velocity $\left(\mathrm{m} \mathrm{s}^{-1}\right)$ as a function of Reynolds number $(\mathrm{Re})$ of animals while cruising $(\circ)$ and escaping $(\bullet)$ 
is turbulent. Animal body shapes are less than ideal in this respect, so Eq. (9) yields a conservative estimate of $C_{\mathrm{D}}$, as can be seen by comparison to actual measurements or models that account for differences in shape (Table 2).

It is reasonable to assume that the body width: length ratio $(W / L)$ is, in general, of the order of $10^{-1}$. Substituting $S_{\mathrm{w}}=2 W L$, taking $C_{\mathrm{D}}$ from Eq. (9), and multiplying both sides of Eq. (8) by $\left(L v^{2} / L v^{2}\right)$, we obtain (in $\mathrm{N}$ )

$$
D=7.2 \times 10^{-3} \rho u_{\mathrm{C}}^{2} L^{2} \mathrm{Re}^{-0.2}=1.4 \times 10^{-14} \rho \mathrm{Re}^{1.8}
$$

The rate of energy utilization (in $\mathrm{W}$ ) to overcome drag is equal to:

$$
e_{\mathrm{d}}=1.4 \times 10^{-14} \rho \operatorname{Re}^{1.8} u_{\mathrm{c}}
$$

Substituting for the cruising speed as a function of body mass from Eq. (1), and for Re as a function of body mass from Eq. (3) we have

$$
e_{\mathrm{d}}=1.34 \times 10^{-5} \rho M^{1.39}
$$

The rate of turbulent energy production by an animal is equal to its total rate of energy utilization for mechanical activity. However, animals are not $100 \%$ efficient in their use of energy for propulsion. Part of the energy is used to overcome drag implied by the animal's observed swimming speed and results in a forward propulsive force. However, the animal needs to expend additional energy to overcome drag forces created by the swimming mechanism itself, and that additional energy is inefficient with respect to propulsion. For example, the accelerating power stroke of a copepod's swimming leg creates forward thrust; however, in returning to its initial position, the leg decelerates, creating a negative drag force and decreasing the forward thrust (Morris et al. 1985). The force created by the decelerating stroke not only requires the animal to expend more energy than would be expected from its observed swimming speed, but also introduces that additional kinetic energy into the medium. The propulsive efficiency may be expressed as:

$$
\eta=\frac{e_{\mathrm{d}}}{e_{\mathrm{t}}}
$$

where $e_{\mathrm{t}}$ is the total rate of energy utilization by an individual animal.

Measurements and estimates of $\eta$ vary widely for animals capable of operating at turbulent Re, and generally increase with body mass. Propulsive efficiency of the copepod Pleuromamma xiphias increases with swimming speed from 0.30 to 0.35 (Morris et al. 1985). The horse mackerel Trachurus trachurus has an efficiency of 0.40 at maximum sustainable swimming speed (Wardle et al. 1996). Fusiform fishes can attain a propulsion efficiency of 0.75 (Lighthill 1970), and some odontocete cetaceans are almost perfect, falling in the range of 0.82 to 0.90 (Fish 1998).

We now have a means of estimating the rate of kinetic energy production by an individual swimming animal, by combining Eqs. (12) \& (13). However, to make a comparison with observed rates of turbulent energy dissipation, we need to take into account groups of animals, and we need to express their rates of energy production per unit mass of seawater. The total rate of energy production $\left(\mathrm{W} \mathrm{kg}^{-1}\right)$ by a group of animals $\left(E_{\mathrm{p}}\right)$ is:

$$
E_{\mathrm{p}}=\frac{e_{\mathrm{d}}}{\eta} \cdot \frac{1}{\rho} \cdot \frac{N}{V}
$$

where $N / V$ is the numerical abundance of the group (numbers $\mathrm{m}^{-3}$ ). Substituting Eq. (12), this simplifies to:

$$
E_{\mathrm{p}}=\frac{1.34 \times 10^{-5} M^{1.39}}{\eta} \cdot \frac{N}{V}
$$

The rate of turbulent energy production by animals will be balanced only by its rate of dissipation $(\varepsilon)$ such that:

$$
E_{\mathrm{p}} \equiv-\varepsilon
$$

Thus, we now have a basis for comparing animalinduced turbulence to observed rates of turbulent energy dissipation.

Table 2. Drag coefficient $\left(C_{\mathrm{D}}\right)$. Selected measurements (Actual) compared to the theoretical value (Estimate) for turbulent flow across a flate plate parallel to the flow (Hoerner 1965)

\begin{tabular}{|lccccccc|}
\hline Species & Mass $(\mathrm{kg})$ & Length $(\mathrm{m})$ & $\mathrm{Re}$ & $C_{\mathrm{D}}$ Estimate & $C_{\mathrm{D}}$ Actual & Actual/Estimate & Source \\
\hline Pleuromamma xiphias & 0.00001 & 0.006 & $3.77 \times 10^{2}$ & 0.0220 & 0.7400 & 33.7 & Morris et al. (1985) \\
Salmo gairdneri & 0.25 & 0.3 & $3.00 \times 10^{5}$ & 0.0056 & 0.0150 & 2.6 & Webb (1975) \\
Pygoscelis adeliae & 4.0 & 0.7 & $1.10 \times 10^{6}$ & 0.0045 & 0.0360 & 8.3 & Culik et al. (1994) \\
Eumetopias jubatus & 141 & 2.32 & $5.50 \times 10^{6}$ & 0.0032 & 0.0046 & 1.4 & Stelle et al. (2000)) \\
Tursiops truncatus & 225 & 2.61 & $1.30 \times 10^{7}$ & 0.0027 & 0.0076 & 2.8 & Fish (1998) \\
Pseudorca crassidens & 487 & 3.75 & $1.80 \times 10^{7}$ & 0.0026 & 0.0046 & 1.8 & Fish (1998) \\
Delphinapterus leucas & 671 & 3.64 & $1.20 \times 10^{7}$ & 0.0028 & 0.0130 & 4.7 & Fish (1998) \\
Orcinus orca & 1601 & 4.74 & $3.65 \times 10^{7}$ & 0.0022 & 0.0026 & 1.2 & Fish (1998) \\
\hline
\end{tabular}




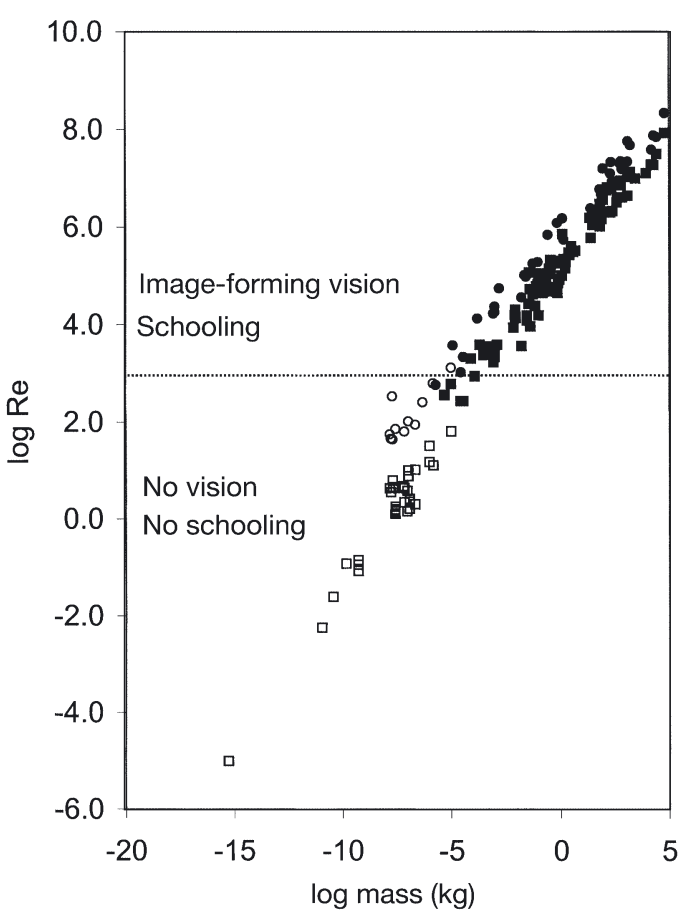

Fig. 4. Reynolds number (Re) as a function of body mass (kg) at both cruising (squares) and escape speeds (circles), distinguishing between animals with image-forming vision and schooling behavior (closed symbols) and those without (open symbols)

\section{Turbulence, vision, and social aggregation}

Animals with body mass $M>10^{-5} \mathrm{~kg}$ operate in a turbulent environment. These larger animals are characterized by 2 important physiological and behavioral attributes that differentiate them from animals operating in a viscous environment. First, they have highly evolved visual systems capable of forming images. Second, their social aggregations are distinguished from those of smaller animals by the phenomenon of schooling, a behavior in which groups of animals are equally orientated, regularly spaced, and swimming at the same speed (Breder \& Halpern 1946). The Re distinction between schooling and non-schooling animals is clearly shown by re-plotting our data set and distinguishing only with regard to visual ability and schooling behavior (Fig. 4).

The visual organs of bacteria, protozoa and copepods, whose swimming speeds place them in the viscous domain, have no image-forming capability; their visual abilities are limited to simple photoreception. Compound eyes of higher crustaceans, which operate at relatively low Re and therefore short length scales, are better able to focus on objects at shorter distances than the camera eyes of vertebrates (Goldsmith 1973).
It is well known that vision plays a dominant role in the schooling behavior of animals with compound and camera eyes (Hunter \& Coyne 1982, Azuma \& Iwata 1994, Wiese 1996, Buskey 2000). More importantly, evolved vision enables animals that operate at high $\mathrm{Re}$ to maintain highly contagious distributions.

\section{Animal abundance in schools}

Schooling behavior occurs in approximately $80 \%$ of all fishes (Burgess \& Shaw 1979), many species of aquatic mammals (Ridgway \& Harrison 1985, 1996), and is common among larger crustaceans (Mauchline 1980, Dall et al. 1990). To understand the potential impact of schooling animals on turbulent mixing in the ocean, we must consider quantitatively both the animals' abundance within aggregations and the volumes occupied by such aggregations.

The most accurate observations of localized abundance within schools (Table 3) have been gained either by the analysis of photographs (Serebrov 1976, Graves 1977, Hamner 1984, Lutcavage et al. 2000, Hanrahan \& Juanes 2001) or targeted sampling of acoustic features (Misund 1993, Lee \& Lee 1996, Misund \& Coetzee 2000). We emphasize that abundances shown in Table 3 are averages reported by the authors, and that greater abundances do occur. The abundance of Antarctic krill is the maximum reported by Hamner (1984); greater abundances of $5 \times 10^{4}$ to $6 \times 10^{4} \mathrm{~m}^{-3}$ (Ragulin 1969), and greater biomass, up to $15 \mathrm{~kg} \mathrm{~m}^{-3}$ (Nemoto 1962), have been observed, but provided no means to estimate the size of animals involved. The northern anchovy Engraulis mordax has been observed at packing densities as high as $533 \mathrm{~m}^{-3}$ (Hewitt 1975), and, although Graves (1977) observed a maximum of $366 \mathrm{~m}^{-3}$, we use his mean of $115 \mathrm{~m}^{-3}$.

Schools tend to be comprised of animals of similar size (Fréon \& Misund 1999). Packing density is inversely proportional to the cube of the minimum nearest neighbor distance (Serebrov 1976), and therefore we expect maximum packing densities (no. $\mathrm{m}^{-3}$ ) to be inversely related to the average mass of the animals in the school. Indeed, we find:

$$
\frac{N}{V}=0.64 M^{-1.2}
$$

(n $=16, \mathrm{r}^{2}=0.99$ ) (Fig. 5) where $N / V$ is the maximum reported packing density in a school of animals of mass $M$.

Serebrov (1976) compiled photographic data on packing densities of fishes ranging in mass from approximately 0.3 to $5 \mathrm{~kg}$ and found that abundance could be described by the relation $N / V=(2.44 L)^{-3}$. The data we have compiled (Fig. 5) extends over a much 
Table 3. Abundances reported in schools of marine animals. Mass of the average animal, average abundance, and biomass in the school of volume and vertical thickness. n: number of observations

\begin{tabular}{|c|c|c|c|c|c|c|c|}
\hline Species & $\begin{array}{c}\text { Mass } \\
(\mathrm{kg})\end{array}$ & $\begin{array}{l}\text { Abundance } \\
\left(\text { no. } \mathrm{m}^{-3}\right)\end{array}$ & $\begin{array}{l}\text { Biomass } \\
\left(\mathrm{kg} \mathrm{m}^{-3}\right)\end{array}$ & $\begin{array}{l}\text { School } \\
\text { vol }\left(\mathrm{m}^{3}\right)\end{array}$ & $\begin{array}{l}\text { Thickness } \\
(\mathrm{m})\end{array}$ & $\mathrm{n}$ & Source \\
\hline Dioithona oculata & $2.2 \times 10^{-7}$ & $3.5 \times 10^{7}$ & 7.70 & & & 22 & Buskey et al. (1996) \\
\hline Nyctiphanes australis & $1.4 \times 10^{-5}$ & 430000 & 6.02 & 15 & 1.0 & 1 & O'Brien (1988) \\
\hline Euphausia superba & $0.0002^{\mathrm{a}}$ & 30000 & 6.0 & 4000 & 4 & $>8$ & Hamner (1984) \\
\hline Engraulis japonicus & 0.002 & 1294 & 2.59 & 4600 & $3.3^{\mathrm{b}}$ & 39 & Lee \& Lee (1996) \\
\hline Engraulis mordax & 0.010 & 115 & 1.15 & & & 10 & Graves (1977) \\
\hline Engraulis encrasicholus & $0.027^{\mathrm{c}}$ & 33.0 & 0.88 & & & & Radakov (1973) \\
\hline Sardinops sagax & 0.033 & 29.5 & 0.97 & & $5^{\mathrm{d}}$ & 1131 & Misund \& Coetzee 2000) \\
\hline Mallotus villosus & $0.049^{c}$ & 15.7 & 0.78 & & & & Zaferman (1973) \\
\hline Boreoqadus saida & $0.097^{\mathrm{c}}$ & 13.6 & 1.32 & & & & Serebrov (1976) \\
\hline Gadus morhua & $0.30^{\mathrm{c}}$ & 4.7 & 1.40 & & & & Serebrov (1976) \\
\hline \multirow[t]{2}{*}{ Clupea harengus } & 0.30 & 4.7 & 1.40 & & & 47 & Misund (1993) \\
\hline & $0.38^{\mathrm{c}}$ & 3.2 & 3.20 & & & & Lyamin (1966) \\
\hline Pollachius virens & $2.30^{\mathrm{C}}$ & 0.25 & 0.57 & & & 7 & Misund (1993) \\
\hline Macrurus rupestris & $4.90^{\mathrm{c}}$ & 0.13 & 0.64 & & & & Serebrov (1976) \\
\hline \multirow{2}{*}{ Thunnus thynnus } & 12 & 0.023 & 0.24 & $8600^{\mathrm{e}}$ & $5^{\mathrm{f}}$ & 74 & Hanrahan \& Juanes (2001) \\
\hline & 135 & $0.001^{\mathrm{g}}$ & 0.14 & $165000^{\mathrm{h}}$ & & 4 & Lutcavage et al. (2000) \\
\hline \multicolumn{8}{|c|}{$\begin{array}{l}{ }^{a} \text { Hamner (1984) does not provide length or mass measurements of the krill, however his observation of sustained swimming } \\
\text { speeds of } 20 \mathrm{~cm} \mathrm{~s}^{-1} \text { are equivalent to those measured for krill of approximately } 33 \mathrm{~mm} \text { (Kils 1979) with a wet weight of } \\
\sim 200 \mathrm{mg} \text { (Zhou et al. 1994) }\end{array}$} \\
\hline \multicolumn{8}{|c|}{ bschool thickness reported for Engraulis japonicus was $3.3 \mathrm{~m}$ in daytime and $16.3 \mathrm{~m}$ at night (Ohshimo 1996) } \\
\hline \multicolumn{8}{|c|}{ 'Mass $(\mathrm{kg})$ estimated from length $(\mathrm{m})$ in our data set in Appendix 1, i.e. $M=10.6 L^{2.8}$} \\
\hline \multicolumn{8}{|c|}{ d The echo sounder depth interval in which schools were recorded } \\
\hline \multicolumn{8}{|c|}{$\begin{array}{l}\text { eVolume based on a typical school size of } 200 \text { individuals (Lutcavage et al. 2000), and thickness of the school estimated based } \\
\text { on experimental data obtained by Hanrahan \& Juanes (2001) }\end{array}$} \\
\hline \multicolumn{8}{|c|}{${ }^{\mathrm{f}}$ Thickness of the tuna school was estimated indirectly from information provided } \\
\hline \multicolumn{8}{|c|}{${ }^{g}$ Abundance was estimated from the experimental data of Hanrahan \& Juanes (2001) } \\
\hline \multicolumn{8}{|c|}{$\begin{array}{l}{ }^{h} \text { Of the } 5 \text { tuna in this weight range }(113 \text { to } 159 \mathrm{~kg}), 4 \text { were in schools of approximately } 200 \text { individuals each (Lutcavage et } \\
\text { al. 2000) }\end{array}$} \\
\hline
\end{tabular}

broader range of animal size - 9 orders of magnitude - yet the resulting Eq. (17) accurately describes Serebrov's (1976) data. Misund (1993, his Fig. 3) showed that Serebrov's equation reasonably well described the upper bound of packing densities he measured acoustically for 532 schools of herring (Clupea harengus), saithe (Pollachius virens) and sprat (Sprattus sprattus). By contrast, the length-to-packing density relationship proposed by Pitcher \& Partridge (1979) overestimated Misund's observations by approximately 1 order of magnitude; their relationship was based on observations of very small captive schools and may describe an upper limit to packing density not commonly observed in free-ranging animals.

Apart from the photographic observations included in Table 3, estimates of packing densities of krill and fishes are based upon either acoustic measurements or net catches. Both of these methods inherently give rise to underestimates. As Misund (1993, p. 153) points out, 'most sources of error in connection with the acoustic method will contribute to underestimate the fish density in schools.' In particular, he cites vessel avoidance reactions and the extinction of sound energy within schools as key factors that lead to underestimates of packing density. Most published reports of biomass based on acoustic measurements are likely to be underestimates. Data from catches in nets and trawls

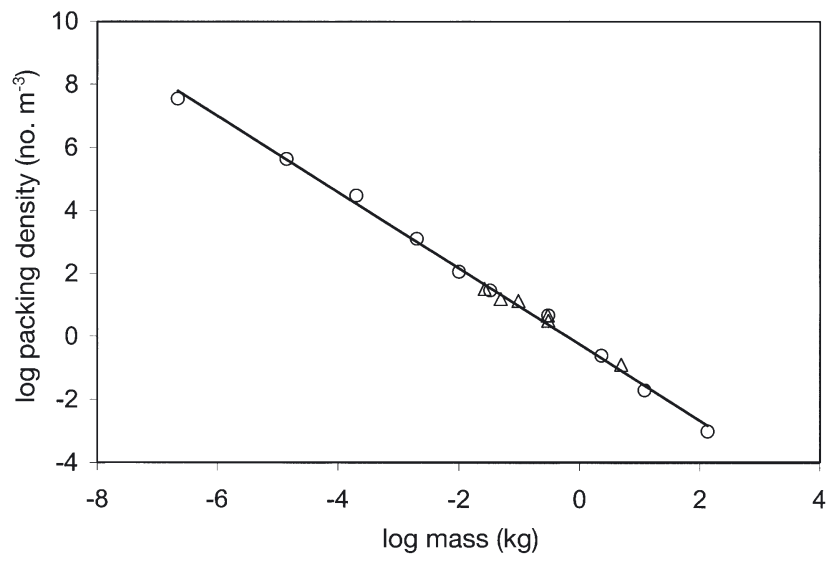

Fig. 5. Abundance or packing density (no. $\mathrm{m}^{-3}$ ) in schooling animals as a function of body mass $(\mathrm{kg})$ for species ranging from copepods to Atlantic bluefin tuna. Data, also provided in Table 3, include those previously reported by Serebrov $(1976)(\Delta)$ 
are also likely to yield significant underestimates, as avoidance behavior to these devices is well known (Fréon \& Misund 1999).

We make 3 important assumptions regarding the packing density of schooling animals. First, we assume that direct observations of free-swimming schools provide the best estimates of packing density, and therefore that Eq. (17) is accurate, at least to within 1 order of magnitude. Second, we assume that acoustic data reasonably well describe the spatial dimensions of schools of krill and small fishes. Third, we assume the packing density of large fishes and aquatic mammals can be reasonably estimated from an extrapolation of Eq. (17). The number of animals in groups of bluefin tuna, sharks or baleen whales is usually reported. To estimate their packing density we assume that the nearest-neighbor distance relationship implied by Eq. (17) holds true.

\section{Magnitude and length scale of turbulent energy production by animal schools}

To assess whether or not animal-induced turbulence is significant in the ocean, we must know not only its magnitude, but also its characteristic spatial and temporal scales.

The kinetic energy production rate for schooling animals of mass $M$ depends not only on their local abundance, but also on their propulsive efficiency (Eq. 13), which can vary significantly among species (Table 4). The crustacean Euphausia pacifica exhibits a maximal propulsive efficiency of $\eta=0.11$ (Torres 1984) if one takes into account a muscle efficiency of 0.25 (Hill 1950). For fishes we estimate propulsive efficiency from:

$$
\eta=0.39 u_{\mathrm{c}}^{0.24}
$$

(Weihs 1977, Wardle et al. 1996), which yields a value of approximately 0.3 for sardines and anchovies and 0.4 for Atlantic bluefin tuna. Odontocete cetaceans attain observed efficiencies in the range of 0.8 to 0.9 (Fish 1998).

We can now calculate the rate of energy production by schools of known packing density from Eq. (15), and by using values of $\eta$ from either direct observation or estimated from Eq. (18). Table 4 shows this result for 11 species of animals, ranging over 8 orders of magnitude in body mass. Interestingly, the estimated rates of kinetic energy production from animal schools are all of the same order, regardless of animal size (Table 4), resulting in $\varepsilon=10^{-5} \mathrm{~W} \mathrm{~kg}^{-1}$.

Scales of animal-induced turbulence will be consistent with the typical length scales of schooling aggregations. A review of thousands of observations on schools of 9 species shows that typical horizontal scales are of the order of $10^{1}$ to $10^{3} \mathrm{~m}$; the thickness or vertical scale of schools is typically from 5 to $50 \mathrm{~m}$ (Table 5).

\section{Observed rates of turbulent energy dissipation in the ocean}

The rate of turbulent energy dissipation $(\varepsilon)$ in the upper mixed layer of the ocean is generally in the range of $10^{-7}$ to $10^{-5} \mathrm{~W} \mathrm{~kg}^{-1}$. Within the pycnocline,

Table 4. Rate of kinetic energy production $\left(E_{\mathrm{p}}\right)$ by schools of representative species of animals. Mass and abundance are taken from sources cited in Appendix 1 or Table 3 or, for animals larger than $10 \mathrm{~kg}$, by extrapolation of Eq. (17). Cruising speed is taken either from Eq. (1) or from the reference indicated; propulsive efficiency $(\eta)$ is taken either from Eq. (18) or from the reference indicated

\begin{tabular}{|c|c|c|c|c|c|}
\hline Species & Mass (kg) & Abundance $\left(\right.$ no. $\mathrm{m}^{-3}$ ) & Speed $\left(\mathrm{m} \mathrm{s}^{-1}\right)$ & $\eta$ & $E_{\mathrm{p}}\left(\mathrm{W} \mathrm{kg}^{-1}\right)$ \\
\hline Euphausia superba & 0.0002 & 30000 & 0.05 & $0.11^{\mathrm{a}}$ & $2.64 \times 10^{-5}$ \\
\hline Engraulis japonicus & 0.002 & 1294 & 0.09 & 0.22 & $1.41 \times 10^{-5}$ \\
\hline Engraulis mordax & 0.010 & 115 & 0.14 & 0.24 & $1.06 \times 10^{-5}$ \\
\hline Sardinops sagax & 0.033 & 29.4 & 0.19 & 0.26 & $1.31 \times 10^{-5}$ \\
\hline Clupea harengus & 0.30 & 4.7 & 0.35 & 0.30 & $3.90 \times 10^{-5}$ \\
\hline Pollachius virens & 2.30 & 0.25 & $1.05^{\mathrm{b}}$ & 0.39 & $2.70 \times 10^{-5}$ \\
\hline Thunnus albacares & 77 & 0.0035 & 1.59 & 0.44 & $4.49 \times 10^{-5}$ \\
\hline Tursiops truncatus & 215 & 0.0010 & $3.35^{\mathrm{c}}$ & $0.85^{\mathrm{c}}$ & $2.80 \times 10^{-5}$ \\
\hline Thunnus thynnus & 318 & $6.5 \times 10^{-4}$ & 1.30 & 0.48 & $5.36 \times 10^{-5}$ \\
\hline Orcinus orca & 1645 & $8.9 \times 10^{-5}$ & $3.95^{\mathrm{c}}$ & $0.87^{\mathrm{c}}$ & $4.03 \times 10^{-5}$ \\
\hline Physeter macrocephalus & 19850 & $4.5 \times 10^{-6}$ & $2.08^{\mathrm{d}}$ & $0.83^{\mathrm{e}}$ & $6.77 \times 10^{-5}$ \\
\hline \multicolumn{6}{|c|}{${ }^{\mathrm{a}}$ Torres (1984) } \\
\hline \multicolumn{6}{|c|}{${ }^{\mathrm{b}}$ Average swimming speed of free-swimming saithe schools (Pedersen 2001) } \\
\hline \multirow{2}{*}{\multicolumn{6}{|c|}{${ }^{c}$ Direct measurements of cruising speed and propulsive efficiency (Fish 1998) }} \\
\hline & & & & & \\
\hline eApproximated from mea & rements on & iite whale Delphinap & eucas (Fish 19 & & \\
\hline
\end{tabular}


Table 5. Spatial scales of schooling animals. Depth is the reported average depth $(\mathrm{m})$ of the school relative to the ocean surface. 'Thickness' is the vertical extent $(\mathrm{m})$ of the school. Average length is the approximate horizontal length scale $(\mathrm{m})$, being either the diameter or cross-wise length of the school relative to its orientation. 'Maximum length' is the horizontal length scale (m) of the largest reported schools. N: number of school observations

\begin{tabular}{|c|c|c|c|c|c|c|}
\hline Species & $\begin{array}{l}\text { Depth } \\
\text { (m) }\end{array}$ & $\begin{array}{l}\text { Thickness } \\
\text { (m) }\end{array}$ & $\begin{array}{l}\text { Average } \\
\text { length } \\
\text { (m) }\end{array}$ & $\begin{array}{l}\text { Maximum } \\
\text { length } \\
\text { (m) }\end{array}$ & $\mathrm{N}$ & Source \\
\hline \multirow[t]{4}{*}{ Euphausia superba } & 55 & 6.5 & 137 & & 1567 & Miller \& Hampton (1989) \\
\hline & $10-240^{\mathrm{a}}$ & $40-60$ & $100-500$ & 12000 & 3364 & Macaulay et al. (1984) \\
\hline & 49 & 6.3 & 94 & & 5624 & BIOMASS (1986) \\
\hline & 61 & 48 & 307 & 677 & 38 & Ricketts et al. (1992) \\
\hline \multirow[t]{3}{*}{ Engraulis mordax } & $12-35$ & 4 & & & 359 & Holliday \& Larsen (1979) \\
\hline & & & 15 & 160 & 1499 & Hewitt et al. (1976) \\
\hline & $0-30$ & $4-15$ & 15 & 180 & 23000 & Mais (1974) \\
\hline Engraulis japonicus & 15 & 3.3 & 16.3 & & b & Ohshimo (1996) \\
\hline \multirow{4}{*}{ Clupea harengus } & $10-60$ & 13 & 55 & 84 & $90^{\mathrm{c}}$ & Misund et al. (1992), Misund (1993) \\
\hline & $5-50$ & 20 & 45 & 89 & $52^{\mathrm{d}}$ & Misund et al. (1992), Misund (1993) \\
\hline & $25-65$ & 22 & 37 & & 47 & Nøttestad et al. (1996) \\
\hline & 40 & 10 & & & & Mathisen et al. (1983) \\
\hline Pollachius virens & $12-20$ & 10 & 28 & 100 & 17 & Misund et al. (1992, Misund (1993) \\
\hline Thunnus albacares & $20-30$ & $5-10$ & $80^{\mathrm{e}}$ & & $124^{\mathrm{e}}$ & Blackburn (1965), Josse \& Bertrand (2000) \\
\hline Tursiops truncatus & $0-20$ & $5-10$ & $55^{\mathrm{f}}$ & $447^{9}$ & & Kenney (1990) \\
\hline Thunnus thynnus & $0-30$ & $2-10$ & 114 & 446 & $126^{\mathrm{h}}$ & Lutcavage et al. (2000), Brill et al. (2002) \\
\hline Orcinus orca & $0-30$ & 5 & $75^{\mathrm{i}}$ & $335^{\mathrm{i}}$ & & Mikhalev et al. (1981), Dahlheim et al. (1982) \\
\hline $\begin{array}{l}{ }^{\mathrm{a}} \text { Krill center of mass } \\
{ }^{\mathrm{b}} \text { Approximately } 500 \\
{ }^{\mathrm{c}} \text { Herring schools obs } \\
{ }^{\mathrm{d}} \text { Herring schools obs } \\
{ }^{\mathrm{e}} \text { Based on a mean of } \\
{ }^{\mathrm{f}} \text { Normal group size o } \\
{ }^{\mathrm{g}} \text { Based on groups of } \\
{ }^{\mathrm{h}} \text { Based on a mean of } \\
{ }^{\mathrm{i}} \text { Based on mean grou }\end{array}$ & $\begin{array}{l}\text { round mic } \\
\mathrm{m} \text { of acou } \\
\text { rved in M } \\
\text { rved in M } \\
22 \text { yellow } \\
\text { up to } 15 \text { ( } \\
\text { round } 100 \\
34 \text { individu } \\
\text { size of } 5\end{array}$ & $\begin{array}{l}\text { dnight } \\
\text { stic transect } \\
\text { løre fjord in } \\
\text { Iøre fjord in } \\
\text { ffin tuna per } \\
\text { (Shane et al. } \\
00 \text { observed } \\
\text { uals per sch } \\
\text { and maxim }\end{array}$ & $\begin{array}{l}\text {, but numk } \\
988 \\
987 \\
\text { school (Au } \\
\text { 1986) } \\
\text { ff South A } \\
\text { ol and a m } \\
\text { m group si }\end{array}$ & $\begin{array}{l}\text { Pitman } 198 \\
\text { ica (Saayma } \\
\text { ximum grou } \\
\text { es of } 100\end{array}$ & $\begin{array}{l}\text { 86) } \\
\text { an et al. } \\
\text { ap size or }\end{array}$ & $\begin{array}{l}\text { 73) } \\
294 \text { (Lutcavage \& Kraus 1995) }\end{array}$ \\
\hline
\end{tabular}

where turbulence is suppressed by the strong vertical density gradient, $\varepsilon$ decreases to about $10^{-10}$ to $10^{-6}$ (Table 6). The variability of dissipation rate within these layers is very high, but boundary values are quite robust. On a seasonal scale, the surface mixed layer shallows in summer to about 5 to $20 \mathrm{~m}$ and deepens in winter to approximately 50 to $70 \mathrm{~m}$ as seasonally averaged wind stress increases significantly.

Turbulent energy dissipation rates are notoriously patchy. Daily or hourly variations of $\varepsilon$ in the upper mixed layer are well documented, with broad-scale variability of approximately 2 orders of magnitude attributed to nocturnal convection (Brainerd \& Gregg 1995) or wind

Table 6. Representative values of turbulent energy dissipation rate $\left(\varepsilon\left[\mathrm{W} \mathrm{kg}^{-1}\right]\right)$ in oceanic regions in the upper mixed layer $\left(\varepsilon_{\mathrm{m}}\right)$ and within the region of maximum stratification $\left(\varepsilon_{\mathrm{s}}\right)$. The mixed layer depth $\left(Z_{\mathrm{m}}\right)$ is the approximate depth below the surface $(\mathrm{m})$ to the top of the thermocline or pycnocline

\begin{tabular}{|c|c|c|c|c|c|c|}
\hline & Region & Season & $Z_{\mathrm{m}}(\mathrm{m})$ & $\begin{array}{l}\text { Mixed } \log \varepsilon_{\mathrm{m}} \\
\left(\mathrm{W} \mathrm{kg}^{-1}\right)\end{array}$ & $\begin{array}{l}\text { Stratified } \log \varepsilon_{\mathrm{s}} \\
\quad\left(\mathrm{W} \mathrm{kg}^{-1}\right)\end{array}$ & Source \\
\hline \multirow[t]{6}{*}{ Coastal/Shelf } & Georges Bank & Apr-May & $10-20$ & -7 to -6 & -9 to -7 & Lough \& Mountain (1996) \\
\hline & & Jul-Aug & $5-15$ & -7 to -6 & -7 to -6 & Horne et al. (1996) \\
\hline & Oregon & Summer & $10-15$ & -6 to -5 & -8 to -6 & Anis \& Moum (1995) \\
\hline & California & Oct & $40-50$ & -8 to -5 & -9 to -7 & Brainerd \& Gregg (1995) \\
\hline & North Sea & Oct & $40-50$ & -7 to -5 & -8 to -6 & Visser et al. (2001) \\
\hline & Black Sea & Oct & 20 & -9 to -8 & -10 to -9 & Lozovatsky et al. (1999) \\
\hline \multirow[t]{3}{*}{ Open ocean } & Equatorial Pacific & Feb-Mar & $60-70$ & -7 to -5 & -9 to -7 & Brainerd \& Gregg (1995) \\
\hline & & Nov-Dec & $20-30$ & -7 to -5 & -8 to -6 & Brainerd \& Gregg (1995) \\
\hline & & Nov & 50 & -7 to -5 & -9 to -8 & Moum et al. (1995) \\
\hline
\end{tabular}


forcing (Visser et al. 2001). On a vertical scale of the order of $1 \mathrm{~m}, \varepsilon$ may vary by 2 orders of magnitude (Brainerd \& Gregg 1995). Similar variations have been observed on horizontal scales of the order of $10^{2} \mathrm{~m}$ (Horne et al. 1996). Repeated microstructure profiles typically show little coherence in small-scale variability.

The observed scales of variability in turbulent energy dissipation rates - order of $1 \mathrm{~m}$ in the vertical, $10^{2} \mathrm{~m}$ in the horizontal, and hours in time - are consistent with the scales of animal-induced turbulence. Small scales of variability may be attributed to a wide variety of factors, such as wind events, rainfall, nocturnal convection, or even to natural variability (Moum et al. 1995, p. 353). We suggest that animal schools could reasonably account for some of that natural variability.

\section{Animal-induced turbulence}

Atlantic bluefin tuna

Thunnus thynnus ranges throughout the North Atlantic Ocean, breeding in the Gulf of Mexico and in the Mediterranean. It moves northward to rich feeding grounds during summer and fall, and is capable of making rapid transatlantic crossings (Block et al. 2001). Adults can attain a mass $>650 \mathrm{~kg}$ and a length of $>3 \mathrm{~m}$ (Magnuson et al. 1994).

Bluefin schools typically arrive in coastal and continental shelf waters of the northwest Atlantic Ocean during summer, when the seasonal thermocline has been well established and stratification is at an annual maximum. Average group size is approximately 100 animals, and schools of $>1000$ are not uncommon (Lutcavage \& Kraus 1995). Schools of more than 40 to 50 tend to be organized in up to 5 layers, thus covering a depth range of approximately $10 \mathrm{~m}$ (Hanrahan \& Juanes 2001). At observed packing densities, $300 \mathrm{~kg}$ animals in a school of average size will occupy $>1.2 \times$ $10^{4} \mathrm{~m}^{2}$; the largest observed schools of $>5000$ (Lutcavage et al. 2000) will cover more than $5.0 \times 10^{5} \mathrm{~m}^{2}$.

Free-ranging bluefin in the Gulf of Maine in summer typically consist of animals in the 100 to $300 \mathrm{~kg}$ sizeclass. Extensive telemetry data show that these animals have sustained swimming speeds $>2.5 \mathrm{~m} \mathrm{~s}^{-1}$, can maintain speeds of up to $3.6 \mathrm{~m} \mathrm{~s}^{-1}$ for about $45 \mathrm{~min}$, and may swim at $>7 \mathrm{~m} \mathrm{~s}^{-1}$ for brief periods (Lutcavage et al. 2000). During feeding bouts, which involve relatively large schools, tuna behavior appears violent, being described as 'pushing, milling and smashing' (Mather 1962). Like many tuna species, bluefin commonly feed in convergence zones or frontal regions where density gradients are high (Olson et al. 1994). More than $70 \%$ of the time is spent cruising just above or within the thermocline, between 3 and $15 \mathrm{~m}$, with the remainder of the time being divided about equally between the upper 3 to $4 \mathrm{~m}$ and occasional dives to a limit of the 8 to $9^{\circ}$ isotherm (Lutcavage et al. 2000, Brill et al. 2002).

As a source of turbulent energy in the ocean, we can characterize bluefin tuna as follows. During the several-month period of maximum seasonal stratification in shelf and coastal waters off North America, the average bluefin tuna school cruises continuously, generating $5 \times 10^{-5} \mathrm{~W} \mathrm{~kg}^{-1}$ on a length scale of the order of $100 \mathrm{~m}$ (Table 4). Turbulent energy is created precisely where density gradients are greatest - within the seasonal thermocline and in frontal zones - where typical energy dissipation rates are $10^{1}$ to $10^{3}$ times lower (Table 6). The resultant coefficient of vertical eddy viscosity, $A_{z}$ is of the order of $10^{-1} \mathrm{~m}^{2} \mathrm{~s}^{-1}$. A school of average size will impact about $20 \mathrm{~km}^{2}$ daily; large schools will affect an area well in excess of $100 \mathrm{~km}^{2}$.

\section{Herring}

Clupea harengus, the North Atlantic herring, provides the basis for one of the world's most productive fisheries, with key areas of concentration distributed across coastal waters of the temperate North Atlantic from the Gulf of Maine to Georges Bank to the North Sea (FAO 1997). Similar species form important fisheries in the North Pacific (Clupea pallasii) and off the coast of Chile (Strongomera bentincki).

The Norwegian herring stock was heavily fished after World War II, and during the 1960s plummeted to about $1 \%$ of its post-war stock size. By the mid-1990s the population had reached its high historic levels of about 10 million t or $50 \times 10^{9}$ individuals, and is now distributed over large areas of the Norwegian Sea (Fréon \& Misund 1999). The entire spring-spawning population makes an extended feeding migration to the central Norwegian Sea in summer, then returns primarily to a single coastal fjord (e.g. Tysfjord in 1983, Vestfjord in 1991 year class) in September where it overwinters until the following spring spawning season (Huse et al. 2002).

As herring enter the fjord region in September, animals are typically organized in schools 10 to $20 \mathrm{~m}$ thick centered at a depth ranging from $10 \mathrm{~m}$ to $40 \mathrm{~m}$ (Misund et al. 1992, Misund 1993). The average school covers an area of approximately $1 \times 10^{3} \mathrm{~m}^{2}$; the largest of 407 schools observed by Misund et al. (1992) reaching $1.0 \times 10^{4} \mathrm{~m}^{2}$. Average abundance in schools of 25 to $30 \mathrm{~cm}$ herring is 2 to 5 animals $\mathrm{m}^{-3}$, but small-scale patches within schools may be 10 times greater. Freeranging schools tend to have approximately the same swimming speed whether they are migrating, spawning, feeding or searching (Nøttestad et al. 1996). Like other clupeoids, schools tend to disperse at night and become more compact during the day (Pitcher 1986). 
Clupea harengus schools may have significant impact on regional-scale ocean turbulence. At typical observed abundances and cruising speeds, herring schools provide energy input of approximately $4 \times 10^{-5} \mathrm{~W} \mathrm{~kg}^{-1}$ (Table 4). In summer in the Norwegian Sea, as the ocean reaches its peak seasonal stratification, the Norwegian spring spawning population covers a total area of the order of $10^{3} \mathrm{~km}^{2}$, cruising in a 10 to $20 \mathrm{~m}$ thick layer through the region of maximal density gradients where dissipation rates are typically orders of magnitude lower. The entire population then migrates to highly stratified fjords along the central Norwegian coastline, concentrating its turbulent energy production over a much smaller area than during summer.

\section{Anchovy}

Often ranking as the world's number one fishery (FAO 1997), anchovy of different species inhabit temperate coastal regions off southern Europe and the Mediterranean, South Africa, Chile, Peru, Japan and California. Schools of Engraulis mordax, the northern anchovy, were studied extensively in the 1970s when the California fishery was still reasonably active. In a survey of approximately 23000 schools, more than $80 \%$ were in the range of 10 to $30 \mathrm{~m}$ in diameter, with the largest ranging up to almost $400 \mathrm{~m}$ (Mais 1974). A school group as large as $10 \mathrm{~km}$ in diameter has been reported (Smith 1970). Subsequent acoustic surveys showed that E. mordax schools are typically $4 \mathrm{~m}$ thick, and centered almost exactly at the depth of the maximal thermal gradient regardless of season (Holliday \& Larsen 1979). Similar schooling characteristics have been observed for Engraulis japonicus (Lee \& Lee 1996, Ohshimo 1996) and Engraulis encrasicolus (Massé et al. 1996).

The central California stock of Engraulis mordax is concentrated primarily in the Southern California Bight, where it spawns year-round, with a peak from February to April and a minimum from August to October (Lasker \& Smith 1977). The spawning population, comprising individuals of mass $M \geq 1.0 \times 10^{-2} \mathrm{~kg}$, reached an estimated peak of almost $5 \times 10^{12} \mathrm{~kg}$ in the mid-1960s (Vrooman \& Smith 1972). Assuming a packing density of 115 fish $\mathrm{m}^{-3}$ (Graves 1977) and the observed school thickness of $4 \mathrm{~m}$ (Holliday \& Larsen 1979), the central California spawning population would have occupied an area of the order of $10^{4} \mathrm{~km}^{2}$. By analogy, the spawning population of Peruvian anchoveta Engraulis ringens which reached an estimated peak of $2 \times 10^{13} \mathrm{~kg}$ (Csirke 1980), would have occupied an area of approximately $4.0 \times 10^{4} \mathrm{~km}^{2}$ of coastal South American waters before the fishery's collapse in the late 1970s.
Anchovy again generates of the order of $10^{-5} \mathrm{~W} \mathrm{~kg}^{-1}$ (Table 4), and is vertically situated on the maximum thermal gradient where rates of turbulent energy dissipation are commonly $10^{-9}$ to $10^{-7} \mathrm{~W} \mathrm{~kg}^{-1}$ (Brainerd \& Gregg 1995). Historically large populations would have occupied large areas within their coastal ocean habitat.

Krill

The Antarctic krill Euphausia superba has a circumcontinental distribution but is most abundant in coastal shelf regions of the Antarctic Peninsula (Marr 1962, Guzmán 1983), The reported average horizontal length scale of swarms ranges from $17 \mathrm{~m}(\mathrm{n}=1576)$ in the Indian Ocean sector, $34 \mathrm{~m}(\mathrm{n}=166)$ in the Prydz Bay region (Miller \& Hampton 1989), $94 \mathrm{~m}(\mathrm{n}=5624)$ in the West Atlantic sector (BIOMASS 1986); to $307 \mathrm{~m}$ (n= 38) around Elephant Island, near the Antarctic Peninsula (Ricketts et al. 1992). Average thickness of these aggregations likewise varies from 6 to $15 \mathrm{~m}$ in the Indian Ocean, Prydz Bay and West Atlantic areas (Miller \& Hampton 1989) to more than $50 \mathrm{~m}$, particularly where larger swarms have been observed (Ricketts et al. 1992, Zhou et al. 1994). Aggregations with a horizontal length scale of $>10^{3} \mathrm{~m}$ are not uncommon (Kalinowski 1983, Zhou et al. 1994); and the largest ever reported was a superswarm of the order of $2.0 \times$ $10^{4} \mathrm{~m}$, or $450 \mathrm{~km}^{2}$, with greatest abundances generally distributed in a layer of 40 to $50 \mathrm{~m}$ (Macaulay et al. 1984).

Euphausia superba performs diel vertical migration and, like many species of euphausiids, tends to be diffusely distributed within 10 to $20 \mathrm{~m}$ of the surface at night, and concentrated around 35 to $50 \mathrm{~m}$ depth during daytime (Demer \& Hewitt 1995, Watkins \& Murray 2000). However, significant seasonal changes in daylength at high latitudes render these vertical distributions rather invariant during summer and winter. The mean depth of summer krill aggregations $(n=4830)$ in the West Atlantic sector is $36 \mathrm{~m}$ (Miller et al. 1993). Daytime depth distributions in summer tend to coincide with regions of the maximal temperature gradient, which in the Scotia Sea and waters of the coastal Antarctic Peninsula is centered between 30 to $50 \mathrm{~m}$ (Foster \& Middleton 1984, Niiler et al. 1991).

The abundance of krill in schools or swarms is a somewhat contentious issue. Photographic and visual observations place abundances in the order of $5.0 \times 10^{4}$ $\mathrm{m}^{-3}$ (Ragulin 1969, Hamner 1984), which is consistent with previous estimates compiled by Mauchline (1980), and less than implied by biomass estimates of up to $15 \mathrm{~kg} \mathrm{~m}^{-3}$ (Nemoto 1962). Acoustic estimates have generally failed to validate these abundances 
(Watkins \& Murray 2000). However, a correction for target strength recommended by Everson et al. (1990) would increase historical estimates by up to one order of magnitude, and place previous high averages for the West Atlantic sector at a level of approximately $5 \mathrm{~kg}$ $\mathrm{m}^{-3}$ (Macaulay et al. 1984, BIOMASS 1986). Analysis of 1766 aggregations in the Indian Ocean and Prydz Bay regions revealed that inter-aggregation distance followed a Poisson distribution, with a mean of $2.1 \mathrm{~km}$ (Miller \& Hampton 1989). This pattern agrees with observations in the West Atlantic sector, although aggregations there tend to be significantly larger (Kalinowski 1983).

Coastal waters of the Antarctic Peninsula are a principal locus of krill abundance and an important source of recruitment to the population of the Scotia Sea region (Marr 1962, Huntley \& Brinton 1991). To a distance of more than $200 \mathrm{~km}$ offshore, the summer thermocline shoals to near $20 \mathrm{~m}$ depth (Mitchell \& HolmHansen 1991, Niiler et al. 1991). The average krill aggregation, covering an area in the range of $10^{4}$ to $10^{5} \mathrm{~m}^{2}$, would be expected to generate turbulent energy of the order of $2 \times 10^{-5} \mathrm{~W} \mathrm{~kg}^{-1}$ (Table 4 ) over a depth interval of approximately $50 \mathrm{~m}$ that encompasses the seasonal thermocline. At the average interaggregation distance of $2.1 \mathrm{~km}$, the contribution to turbulent mixing could be significant.

The impact of summer krill aggregations on ecosystem dynamics at horizontal length scales of $10^{1}$ to $10^{3} \mathrm{~m}$ could be especially important in critical recruitment areas near the Antarctic Peninsula. Here the first spring bloom significantly reduces the concentration of macronutrients in the upper mixed layer (HolmHansen \& Mitchell 1991, Dore et al. 1992). However, productivity can remain very high with frequent bloom formation over several months following the initial bloom and nutrient depletion (Karl et al. 1992, HolmHansen et al. 1993). Constant erosion of the nitracline at scales of krill-induced mixing would provide a supply of nutrients that could be important to the observed rates of continued high primary productivity. Even at average abundance of 0.1 to $1 \mathrm{~kg} \mathrm{~m}^{-3}$, the rate of kinetic energy production by krill aggregations would still be of the order of $10^{-6} \mathrm{~W} \mathrm{~kg}^{-1}$. This is substantially greater than expected rates of turbulent energy dissipation within the thermocline (Table 6).

\section{CONCLUSIONS}

Animals can be an important source of turbulent energy in the ocean at typical scales of social aggregation. The rate of turbulent energy production by schooling animals, from krill to whales, is $10^{-5}$ to $10^{-4} \mathrm{~W} \mathrm{~kg}^{-1}$, regardless of species. By comparison, the rate of turbulent energy dissipation in the upper $10 \mathrm{~m}$ resulting from a wind of $5 \mathrm{~m} \mathrm{~s}^{-1}$ is $1.7 \times 10^{-7} \mathrm{~W} \mathrm{~kg}^{-1}$, and from a wind of $20 \mathrm{~m} \mathrm{~s}^{-1}, 8.5 \times 10^{-6} \mathrm{~W} \mathrm{~kg}^{-1}$ (MacKenzie \& Leggett 1993).

Horizontal length scales of wind-induced turbulence are substantially greater than typical animal assemblages, which are generally $10^{1}$ to $10^{3} \mathrm{~m}$. However, the horizontal length scales of animal schools are consistent with commonly observed fine-scale variability in $\varepsilon$ (e.g. Brainerd \& Gregg 1995). Many animal species prefer to swim and feed within the zone of maximum vertical stratification, where their rate of turbulent energy production is several orders of magnitude greater than average dissipation rates.

Bluefin tuna schools may not challenge storms in the Gulf of Maine as a regional-scale source of turbulent energy, but they are not the only schooling animals in the region, just as herring are not the only fish in Norwegian fjords, nor are anchovy the only animals in the Southern California Bight. The cumulative impact of all schooling animals in any region is far beyond our ability to estimate. The data simply do not exist.

We do not suggest that animal aggregations are more important than purely physical forces as a source of turbulent energy production. However-particularly in coastal regions, where schooling animals are most abundant, and especially in summer when seasonal stratification is greatest-the mixing energy introduced by swimming animals may have a significant effect not only on local physics, but also on the chemistry and biology of the ocean.

Acknowledgements. We thank colleagues who provided constructive criticism of the manuscript, namely J. B. Graham, E. Hofmann, P. Niiler, T. Osborn, E. Shulenberger, and T. Powell. Particular thanks are due to R. Full at UC Berkeley for suggesting sources of data. This is contribution No. 8 of the Simon J. Poole Institute. The research was supported by US Office of Naval Research grant number NOO014-92-J-618 and US National Science Foundation grant number OCE 0002713 to M.E.H.

\section{LITERATURE CITED}

Anis A, Moum J (1995) Surface wave-turbulence interactions: scaling $\varepsilon(z)$ near the sea surface. J Phys Oceanogr 25: 2025-2045

Au D, Pitman R (1986) Seabird interactions with dolphins and tuna in the eastern tropical Pacific. Condor 88:304-317

Azuma A (1992) The biokinetics of flying and swimming. Springer-Verlag, Tokyo

Azuma T, Iwata M (1994) Influences of illumination intensity on the nearest neighbour distance in coho salmon Oncorhynchus kisutch. J Fish Biol 45:1113-1118

BIOMASS (1986) Post-FIBEX acoustic workshop. BIOMASS Rep Ser 40

Blackburn M (1965) Oceanography and ecology of tunas. Oceanogr Mar Biol Annu Rev 3:299-322

Block BA, Dewar H, Blackwell SB, Williams TD and 7 others 
(2001) Migratory movements, depth preferences, and thermal biology of Atlantic bluefin tuna. Science 293: 1310-1314

Brainerd K, Gregg M (1995) Surface mixed and mixing layer depths. Deep-Sea Res I 42:1521-5143

Breder CJ, Halpern F (1946) Innate and acquired behavior affecting the aggregation of fishes. Physiol Zool 19: $154-190$

Brill R, Lutcavage M, Metzger G, Bushnell P, Arendt M, Lucy J, Watson C, Foley D (2002) Horizontal and vertical movements of juvenile bluefin tuna (Thunnus thynnus), in relation to oceanographic conditions of the western North Atlantic, determined with ultrasonic telemetry. Fish Bull 100:155-167

Burgess J, Shaw E (1979) Development and ecology of fish schooling. Oceanus 27:11-17

Buskey E (2000) Role of vision in the aggregative behavior of the planktonic mysid Mysidium columbiae. Mar Biol 137: 257-265

Buskey E, Peterson J, Ambler J (1996) The swarming behavior of the copepod Diothona oculata: In situ and laboratory studies. Limnol Oceanogr 41:513-521

Caparroy P, Perez M, Carlotti F (1998) Feeding behavior of Centropages typicus in calm and turbulent conditions. Mar Ecol Prog Ser 168:109-118

Cheng JY, Chahine G (2001) Computational hydrodynamics of animal swimming: boundary element method and three-dimensional vortex wake structure. Comp Biochem Physiol A 131:51-60

Costello JH, Strickler JR, Marassé C, Trager GZ, R., Freise AJ (1990) Grazing in a turbulent environment: behavioral response of a calanoid copepod, Centropages hamatus. Proc Natl Acad Sci USA 87:1648-1652

Csirke J (1980) Recruitment in the Peruvian anchovy and its dependence on the adult population. Rapp P-V Réun Cons Int Explor Mer 177:307-313

Culik B, Wilson R, Bannasch R (1994) Underwater swimming at low energetic cost by pygoscelid penguins. J Exp Biol 197:65-78

Dahlheim M, Leatherwood J, Perrin W (1982) Distribution of killer whales in the warm temperate and tropical eastern Pacific. Rep Int Whaling Comm 32:647-653

Dall W, Hill BJ, Rothlisberg PC, Sharples DJ (1990) The biology of the Penaeidae. Adv Mar Biol 27:1-489

Demer D, Hewitt R (1995) Bias in acoustic biomass estimates of Euphausia superba due to diel vertical migration. Deep-Sea Res I 42:455-475

Dore JE, Tien G, Letelier R, Parrish G, Szyper J, Burgett J, Karl DM (1992) RACER: Distributions of nitrogenous nutrients near receding pack ice in Marguerite Bay. Antarct J US 27:177-179

Dower J, Miller T, Leggett W (1997) The role of microscale turbulence in the feeding ecology of larval fish. Adv Mar Biol 31:169-220

Everson I, Watkins J, Bone D, Foote K (1990) Implications of a new acoustic target strength for abundance estimates of Antarctic krill. Nature 345:338-340

FAO (Food and Agriculture Organization) (1997) FAO yearbook, fishery statistics, catches and landings, Vol 46. Food and Agriculture Organization of the United Nations, Rome

Fish F (1998) Comparative kinematics and hydrodynamics of odontocete cetaceans: morphological and ecological, correlates with swimming performance. J Exp Biol 201: 2867-2877

Fish FE (1993) Power output and propulsive efiiciency of swimming bottlenose dolphins (Tursiops truncatus). J Exp Biol 185:179-193
Fish FE, Fegeley JF, Xanthopolous CJ (1991) Burst-and-coast swimming in schooling fish (Notemisgonus crysoleucas) with implications for fish energy economy. Comp Biochem Physiol A 100:633-639

Foster T, Middleton J (1984) The oceanographic structure of the eastern Scotia Sea - I. Physical oceanography. DeepSea Res 31:529-550

Fréon P, Misund O (1999) Dynamics of pelagic fish distribution and behaviour: effects on fisheries and stock assessment. Fishing News Press, Oxford

Gilmore RM (1956) The California gray whale. Zoonooz 29: 4-6

Goldsmith TH (1973) Photoreception and vision. In: Prosser CL (ed) Comparative animal physiology. WB Saunders, Philadelphia, p 577-632

Graves J (1977) Photographic method for measuring spacing and density within anchovy, Engraulis mordax, school groups. Fish Bull 75:679-685

Guzmán O (1983) Distribution and abundance of Antarctic krill (Euphausia superba) in the Bransfield Strait. Ber Polarforsch 4:169-190

Hamner WM (1984) Aspects of schooling in Euphausia superba. J Crustac Biol 4 (Spec. No. 1):67-74

Hanrahan B, Juanes F (2001) Estimating the number of fish in Atlantic bluefin tuna (Thunnus thynnus thynnus) schools using models from captive school observations. Fish Bull 99:420-431

Hewitt R (1975) Sonar mapping in the California Current area: a review of recent developments. Calif Coop Ocean Fish Investig Rep 18:149-154

Hewitt R, Smith P, Brown J (1976) Development and use of sonar mapping for pelagic stock assessment in the California Current area. Fish Bull 74:281-300

Hill A (1950) The dimensions of animals and their muscular dynamics. Sci Prog (Lond) 38:208-230

Hoerner S (1965) Fluid-dynamic drag. SF Hoerner, Brick Town, NJ

Holliday D, Larsen H (1979) Thickness and depth distributions of some epipelagic fish schools off southern California. Fish Bull 77:489-494

Holm-Hansen O, Mitchell BG (1991) Spatial and temporal distribution of phytoplankton and primary production in the western Bransfield Strait region. Deep-Sea Res 38: 961-980

Holm-Hansen O, Villafañe VE, Helbling EW, Sala S (1993) AMLR program: rates of primary production around Elephant Island, Antarctica. Antarct J US 28:191-193

Horne E, Loder J, Naimie C, Oakey N (1996) Turbulence dissipation rates and nitrate supply in the upper water column on Georges Bank. Deep-Sea Res II 43:1683-1712

Hunter J, Coyne K (1982) The onset of schooling in northern anchovy larvae Engraulis mordax. Calif Coop Ocean Fish Investig Rep 23:246-251

Huntley ME, Brinton E (1991) Mesoscale variation in growth and early development of Euphausia superba Dana in the western Bransfield Strait region. Deep-Sea Res 38: $1213-1240$

Huntley ME, Zhou M, Nordhausen W (1995) Mesoscale distribution of zooplankton in the California Current in late spring, observed by Optical Plankton Counter. J Mar Res 53:647-674

Huse G, Railsback S, Fernö A (2002) Modelling changes in migration pattern of herring: collective behaviour and numerical domination. J Fish Biol 60:571-582

Hwang JS, Strickler J (1994) Effects of periodic turbulent events upon escape responses of a calanoid copepod Centropages hamatus. Bull Plankton Soc Jpn 41:117-130 
Josse E, Bertrand A (2000) In situ acoustic target strength measurements of tuna associated with a fish aggregating device. ICES J Mar Sci 57:911-918

Kalinowski J (1983) Elementy biolgii, formy grupo wego wystepowania i zasoby Antarktycznego kryla Euphausia superba Dana/Crustacea. PhD thesis, Sea Fisheries Institute, Gdynia

Karl DM, Amos A, Holm-Hansen O, Huntley ME, Vernet M (1992) RACER: the Marguerite Bay ice-edge reconnaissance. Antarct J US 27:175-177

Kenney R (1990) Bottlenose dolphins off the northeastern United States. In: Leatherwood S, Reeves R (eds) The bottlenose dolphin. Academic Press, San Diego, p 369-386

Kils U (1979) Swimming speed and escape capacity of Antarctic krill, Euphausia superba. Meeresforschung 27:264-266

Kiørboe T, Saiz E (1995) Planktivorous feeding in calm and turbulent environments, with emphasis on copepods. Mar Ecol Prog Ser 122:135-145

Lasker R, Smith P (1977) Estimation of the effects of environmental variations on the eggs and larvae of the northern anchovy. Calif Coop Ocean Fish Investig Rep 19:128-137

Lee M, Lee K (1996) The larval anchovy (Engraulis japonicus) fishery in relation to the environmental factors in coastal waters of Fangliao, Taiwan. Fish Res 26:37-48

Lighthill MJ (1970) Aquatic animal propulsion of high hydrodynamical efficiency. J Fluid Mech 44:265-301

Lough R, Mountain D (1996) Effect of small-scale turbulence on feeding rates of larval cod and haddock in stratified water on Georges Bank. Deep-Sea Res II 43:1745-1772

Lozovatsky I, Dillon T, Erofeev A, Nabatov V (1999) Variations of thermohaline structure and turbulent mixing on the Black Sea shelf at the beginning of autumn cooling. J Mar Syst 21:255-282

Lutcavage M, Kraus S (1995) The feasibility of direct photographic assessment of giant bluefin tuna in New England waters. Fish Bull 95:300-310

Lutcavage M, Brill R, Skomal G, Chase B, Goldstein J, Tutein J (2000) Tracking adult North Atlantic bluefin tuna (Thunnus thynnus) in the northwestern Atlantic using ultrasonic telemetry. Mar Biol 137:347-358

Lyamin K (1966) Biology and fecundity of the spring-spawning herring (Clupea harengus) in the Norwegian Sea. Tr Polyarn n-i i proyektn in-ta morsk rybn Kh-va i okeanogr 17 (cited in Serebrov 1976)

Macaulay MC, English TS, Mathisen OE (1984) Acoustic characterization of swarms of Antarctic krill (Euphausia superba) from Elephant Island and Bransfield Strait. J Crustac Biol 4 (Spec. No. 1):16-44

MacKenzie B, Kiørboe T (1995) Encounter rates and swimming behavior of pause-travel and cruise larval fish predators in calm and turbulent laboratory environments. Limnol Oceanogr 40:1278-1289

MacKenzie B, Kiørboe T (2000) Larval fish feeding and turbulence: a case for the downside. Limnol Oceanogr 45: $1-10$

MacKenzie B, Leggett W (1993) Wind-based models for estimating the dissipation rates of turbulent energy in aquatic environments: empirical comparison. Mar Ecol Prog Ser 94:207-216

Magnuson J, Block B, Deriso R, Gold J and 5 others (1994) An assessment of Atlantic bluefin tuna. National Academy Press, Washington, DC

Mais K (1974) Pelagic fish surveys in the California Current. Calif Fish Game 162:1-72

Marr JWS (1962) The natural history and geography of the Antarctic krill (Euphausia superba Dana). Discov Rep 32: $33-464$
Massé J, Koutsikopoulos C, Patty W (1996) The structure and spatial distribution of pelagic fish schools in multispecies clusters: an acoustic study. ICES J Mar Sci 53: $155-160$

Mather FI (1962) Tunas (genus Thunnus) of the western North Atlantic. Part III: Distribution and behavior of Thunnus species Symposium on scombroid fishes. Marine Biological Association of India, Mandapam, p 1-16

Mathisen O, Lemberg N, Johnson R (1983) Hydroacoustic indices as input to dynamic management systems of fish stocks. FAO Fish Rep 300:223-231

Mauchline J (1980) The biology of mysids and euphausiids. Adv Mar Biol 18:373-595

Mikhalev Y, Ivashin M, Savusin V, Zelenaya F (1981) The distribution and biology of killer whales in the Southern Hemisphere. Rep Int Whaling Comm 1:551-566

Miller DGM, Hampton I (1989) Krill aggregation characteristics: spatial distribution patterns from hydroacoustic observations. Polar Biol 10:125-134

Miller D, Barange M, Klindt M, Murray A, Hampton I, Siegel V (1993) Antarctic krill aggregation characteristics from acoustics in the southwest Atlantic Ocean. Mar Biol 117: 171-183

Misund O (1993) Dynamics of moving masses: Variability in packing density, shape, and size among herring, sprat, and saithe schools. ICES J Mar Sci 50:145-160

Misund O, Coetzee J (2000) Recording fish schools by multibeam sonar: potential for validating and supplementing echo integration recordings of schooling fish. Fish Res 47: 149-159

Misund O, Aglen A, Beltestad A, Dalen J (1992) Relationships between the geometric dimensions and biomass of schools. ICES J Mar Sci 49:305-315

Mitchell BG, Holm-Hansen O (1991) Observations and modeling of the Antarctic phytoplankton crop in relation to mixing depth. Deep-Sea Res 38:981-1007

Morris MJ, Torres JJ, Gust G (1985) Propulsion efficiency and cost of transport for copepods: A hydromechanical model of crustacean swimming. Mar Biol 86:283-295

Morris MJ, Kohlhage K, Gust G (1990) Mechanics and energetics of swimming in the small copepod Acanthocyclops robustus (Cyclopoida). Mar Biol 103:83-91

Moum J, Gregg M, Lien R, Carr M (1995) Comparison of turbulence kinetic energy dissipation rate estimates from two ocean microstructure profilers. J Atmos Ocean Technol 12: $346-366$

Müller U, van den Heuvel B, Stamhuis E, Videler J (1997) Fish foot-prints: morphology and energetics of the wake behind a continuously swimming mullet (Chelon labrosus Risso). J Exp Biol 200:2893-2906

Nemoto T (1962) Food of baleen whales collected in recent Japanese Antarctic expeditions. Sci Rep Whales Res Inst Tokyo 16:89-103

Niiler P, Amos A, Hu J (1991) Water masses and 200 m relative geostrophic circulation in the western Bransfield Strait region. Deep-Sea Res 38:943-959

Nøttestad L, Aksland M, Beltestad A, Fernoe A, Johannessen A, Misund O (1996) Schooling dynamics of Norwegian spring spawning sardine (Clupea harengus L.) in a coastal spawning area. Sarsia 80:277-284

O'Brien D (1988) Surface schooling behaviour of the coastal krill Nyctiphanes australis (Crustacea: Euphausiacea) off Tasmania, Australia. Mar Ecol Prog Ser 42:219-233

Ohshimo S (1996) Acoustic estimation of biomass and school character of Engraulis japonicus in the East China Sea and the Yellow Sea. Fish Sci 62:344-349

Olson D, Hitchcock G, Mariano A, Ashjian C, Peng G, Nero R, 
Podesta G (1994) Life on the edge: marine life and fronts. Oceanography 7:52-60

Omori M, Ikeda T (1984) Methods in marine zooplankton ecology. John Wiley \& Sons, New York

Pedersen J (2001) Hydroacoustic measurement of swimming speed of North Sea saithe in the field. J Fish Biol 58: 1073-1085

Pitcher T (1986) Functions of shoaling behaviour in teleosts. In: Pitcher T (ed) The behaviours of teleost fishes. Croom Helm, London, p 294-337

Pitcher T, Partridge B (1979) Fish school density and volume. Mar Biol 54:383-394

Pond S, Pickard GL (1989) Introductory dynamical oceanography. Pergamon Press, Oxford

Radakov DV (1973) Schooling in the ecology of fish. Halsted Press, J Wiley \& Sons, New York

Ragulin A (1969) Underwater observations on krill. Trudy Vsesyouznogo Naucho-essledovatel'skogo Instituta Morskogo Rybnogo Khosyaitsiva i Okeanografi (Tr VNIRO) 66: 231-234

Rice DW (1989) Sperm whale-Physeter macrocephalus Linnaeus, 1758. In: Ridgway SH, Harrison R (eds) Handbook of marine mammals, Vol 4. Academic Press, London, p $177-233$

Ricketts C, Watkins J, Morris D, Buchholz F, Priddle J (1992) An assessment of the biological and acoustic characteristics of swarms of Antarctic krill. Deep-Sea Res I 39: 350-371

Ridgway SH, Harrison R (eds) (1985) The sirenians and baleen whales, Vol 3. Academic Press, London

Ridgway SH, Harrison R (eds) (1996) The first book of dolphins, Vol 5. Academic Press, London

Rothschild BJ, Osborn TR (1988) Small-scale turbulence and plankton contact rates. J Plankton Res 10:465-474

Saayman G, Tayler C, Bower D (1973) Diurnal activity cycles in captive and free-ranging Indian Ocean bottlenose dolphins (Tursiops truncatus Ehrenberg). Behaviour 44:212-233

Serebrov L (1976) Relationship between school density and size of fish. J Ichthyol 16:135-140

Shane S, Wells R, Würsig B (1986) Ecology, behavior and social organization of the bottlenose dolphin: a review. Mar Mamm Sci 2:34-63

Smith P (1970) The horizontal dimensions and abundance of fish schools in the upper mixed layer as measured by sonar. In: Farquhar G (ed) International Symposium on Sound Scattering in the Ocean. Department of the Navy, Washington, DC, p 563-591

Stelle L, Blake R, Trites A (2000) Hydrodynamic drag in steller sea lions (Eumetopias jubatus). J Exp Biol 203:1915-1923

Strickler JR (1975) Swimming of planktonic Cyclops species (Copepoda, Crustacea): Pattern, movements and their control. In: Wu TYT (ed) Swimming and flying in nature, Vol 1. Plenum Press, New York, p 599-613

Editorial responsibility: Otto Kinne (Editor),

Oldendorf/Luhe, Germany
Torres JJ (1984) Relationship of oxygen consumption to swimming speed in Euphausia pacifica. II. Drag, efficiency and a comparison with other swimming organisms. Mar Biol 78:231-237

Videler JJ, Nolet BA (1990) Costs of swimming measured at optimum speed: scale effects, differences between swimming styles, taxonomic groups and submerged and surface swimming. Comp Biochem Physiol A 97:91-99

Videler J, Stamhuis E, Müller U, van Duren L (2002) The scaling and structure of aquatic animal wakes. Integr Comp Biol 45:988-996

Visser A, Saito H, Saiz E, Kiørboe T (2001) Observations of copepod feeding and vertical distribution under natural turbulent conditions in the North Sea. Mar Biol 138: 1011-1019

Vlymen W (1970) Energy expenditure of swimming copepods. Limnol Oceanogr 15:348-356

Vogel S (1981) Life in moving fluids: the physical biology of flow. Princeton University Press, Princeton, NJ

Vrooman A, Smith P (1972) Biomass of the subpopulations of northern anchovy, Engraulis mordax Girard. Calif Coop Ocean Fish Investig Rep 15:49-51

Wardle C, Soofiani N, O'Neill F, Glass C, Johnstone A (1996) Measurements of aerobic metabolism of a school of horse mackerel at different swimming speeds. J Fish Biol 49: $854-862$

Watkins J, Murray A (2000) Layers of Antarctic krill, Euphausia superba: Are they just long krill swarms? Mar Biol 131: 237-247

Webb PW (1975) Hydrodynamics and energetics of fish propulsion. Bull Fish Res Board Can 190:1-159

Weihs D (1977) Effects of size on sustained swimming speeds of aquatic organisms. In: Pedley T (ed) Scale effects in animal locomotion. Academic Press, London, p 333-338

Whoriskey FG, Wooton RJ (1987) The swimming endurance of threespine sticklebacks, Gasterosteus aculeatus L., from the Afon Rheidol, Wales. J Fish Biol 30:335-339

Wiese K (1996) Sensory capacities of euphausiids in the context of schooling. Mar Freshw Behav Physiol 28: 183-194

Wolman AA (1985) Gray whale-Eschrichtius robustus. In: Harrison R (ed) Handbook of marine mammals, Vol 3. Academic Press, London, p 67-90

Wu $\mathrm{T}$ (1971) Hydrodynamics of swimming fishes and cetaceans. Adv Appl Math 11:1-63

Zaferman ML (1973) Observations on capelin in the area of Hope Island. Transl Ser Fish Res Board Can 2840. (Transl of Nablyudeniya za moivoi rayone o Nade-zhdy. From: Rybokhoz Issled Sev Bass 19:93-100

Zhou M, Nordhausen W, Huntley ME (1994) ADCP measurements of the distribution and abundance of euphausiids near the Antarctic Peninsula in winter. Deep-Sea Res I 41: $1425-1445$

Submitted: August 28, 2003; Accepted: November 11, 2003 Proofs received from author(s): May 25, 2004 